\title{
Prevalence and factors associated with the consumption of folic acid and iron in pregnant women in the BRISA cohort
}

\section{Renata Monteiro Lima 1}

iD https://orcid.org/0000-0003-1406-4278

Elisângela Veruska Nóbrega Crispim Leite 2

https://orcid.org/0000-0001-6248-829X

Danielle França Furtado 3

https://orcid.org/0000-0003-1425-4979

Alcione Miranda dos Santos 4

https://orcid.org/0000-0001-9711-0182

\footnotetext{
1 Departamento de Farmácia. Universidade Federal do Maranhão. Av. dos Portugueses, 1966. Bacanga. São Luís, MA, Brasil. CEP: 65.080-805. E-mail: renata.monteiro.lima@outlook.com

2,3 Unidade Materno Infantil. Hospital Universitário. Universidade Federal do Maranhão. São Luís, MA, Brasil.

${ }^{4}$ Departamento de Saúde Pública.Universidade Federal do Maranhão. São Luís, MA, Brasil.
}

\begin{abstract}
Objectives: to describe the prevalence and factors associated with the consumption of folic acid and iron among puerperal women in the city of São Luis, Maranhão.

Methods: a cross-sectional study with 4,036 puerperal women through a standardized questionnaire. The dependent variables (outcomes) were: the consumption of folic acid during pregnancy, iron and folic acid before pregnancy. The independent variables: age; schooling; skin color; marital status; income; planned pregnancy; place and number of prenatal consultations. Statistical analyzes were performed on STATA 14.0. For the first two outcomes, Poisson model with a robust variance was used. And for the last one, logistic regression.

Results: the prevalence of consuming folic acid and iron during pregnancy were, respectively, $77.27 \%$ and $84.98 \%$. However, only $0.37 \%$ reported the consume of folic acid and iron before pregnancy. In the adjusted analysis, the variables associated with the consumption of folic acid during pregnancy were: schooling and income; the consume of iron during pregnancy, age only; and for those who consumed folic acid before pregnancy, no variable was statistically significant.

Conclusions: high percentage of puerperal women who consumed folic acid and iron supplements during pregnancy, however, the recommended consumption of folic acid before pregnancy was low and maternal, social and economic factors influence the consumption of these supplements.
\end{abstract}

Key words Folic acid, Iron, Prenatal care, Risk factors, Pharmacoepidemiology, Pregnancy

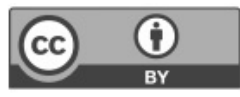




\section{Introduction}

Pregnancy causes physiological changes in the organism which cause an increased need of essential nutrients. ${ }^{1}$ Among these nutrients, the importance of folic acid (FA) and iron (I) supplementation in pregnancy stands out. ${ }^{2}$

FA is essential for the synthesis of deoxyribonucleic (DNA) and ribonucleic (RNA) acids, essential in erythropoiesis and also indispensable in regulating the normal development of nerve cells, in preventing birth defects in the fetal neural tube (NTD) and megaloblastic anemia in mothers.2-4 Whereas Iron supplementation prevents premature birth, maternal and child mortality, infectious diseases, inadequate growth and development, as well as intrauterine and in long term. 5,6

There are evidences that adequate supplementation of FA 7,8 in the first three months before conception and until the end of the first trimester of pregnancy, considerably reduces the risk of NTD, as well as the consumption of Iron during pregnancy prevents complications from maternal anemia.9,10

Although FA and Iron supplementation are recommended by the World Health Organization, 10 during pregnancy, the percentage of women who consume these supplements is persistently low, 11 leading to a high incidence of NTD worldwide, between 0.36 and 1.7 per 1,000 live births. 12 The prevalence of maternal anemia in developing countries remains equally high. 11

In this context, studies are needed to assess the factors associated with the consumption of these supplements to direct public actions, in order to solve these severe public health problems, not only locally, but worldwide. This could really increase the consumption of medications that prevent malformations, diseases and unfavorable outcomes for both the fetus and the mother.

The objective of this study was to describe the prevalence of the consumption of FA and Iron supplementation before and during pregnancy and to analyze the factors associated with its consumption among puerperal women in the city of São Luís, Maranhão.

\section{Methods}

This is a cross-sectional study that used data from a cohort entitled "Fatores etiológicos do nascimento pré-termo e consequências dos fatores perinatais na saúde da criança: coortes de nascimentos em duas cidades brasileiras (BRISA)", (Etiological factors of preterm birth and consequences of perinatal factors on child health: birth cohorts in two Brazilian cities (BRISA), developed by the Universidade Federal do Maranhão in partnership with the Faculdade de Medicina da Universidade de São Paulo in Ribeirão Preto (USP-RP).

This study included only data from the BRISA cohort from the city of São Luís, Maranhão, whose population consisted of 5,110 puerperal women who delivered at a hospital or maternity hospital in the city of São Luís, in the period from January to December 2010.

The sample size was calculated by considering $5 \%$ error in type I, $80 \%$ of power, $1: 1$ ratio between unexposed and exposed (exposure=number of prenatal consultations performed), prevalence of medication use in those not exposed of $50 \%$, prevalence ratio of 1.5 , resulting in an initial sample size of 474 puerperal women (272 exposed and 272 unexposed). Predicting the possibility of a segment loss and / or non-responses, $10 \%$ was added to this value, reaching a minimum sample of 600 women.

During the study period, every day, hospitals and maternity hospitals that performed the childbirths, except those that had fewer than 100 childbirths each year, were visited by the researchers. All births, live or dead, were cataloged using a childbirth control form. In cases where the mother was discharged before the interview, she was interviewed at home, if she lived in São Luís.

The selection of puerperal women was made by a stratified sampling with a proportional number of births in each hospital or maternity hospital included in the study. First, a list of all births that occurred during the day, in each sampled unit, in childbirth order, was listed. For each hospital or maternity in the study, a casual start between one and three was randomly selected. The value of the sampling interval was three. Adding the casual start to the value of the sampling interval and so on, all the puerperal women were randomly selected.

The inclusion criterion adopted was the mother who lived in the city of São Luís and knew what kind of medications she took during her pregnancy, and with this knowledge, it was evaluated for the safety of the puerperal women's answers.

Due to the fact that some pregnant women were unaware or had doubts about which medications they took during pregnancy and / or by the lack of information about some variables of interest, 1,074 pregnant women were excluded from this study.

Therefore, the sample in this study consisted of 4,036 women who delivered at a hospital or maternity hospital in the city of São Luís, which corresponds to $80 \%$ of the study population. 
In the BRISA study, standardized questionnaires were applied to puerperal women, based on their consent. To ensure uniformity of the questions, the interviewers were instructed to always read the questions, instead of formulating them in their own way. The interviews were always carried out in the first 72 hours after childbirth.

Regarding to the data related to the medications consumed during pregnancy, first the puerperal woman was asked if she had taken any medication(s) during her pregnancy. If she responded yes, she was asked the name(s) of the medication(s) and in which month of pregnancy did she begin to take the medication(s) and when did she stop taking it or them. If she continued to take it or them, it was noted down. In relation to the investigation in the use of folic acid before pregnancy, the puerperal woman was asked if she had taken the medication in the three months prior to the pregnancy. If she answered yes, the name(s) of the medication(s) was / were asked. The term medicine was used in the questionnaire to facilitate the interviewees' understanding the use of medications.

The dependent variables of the study were formed by three outcomes: puerperal women who consumed FA during pregnancy (outcome 1), who took Iron during pregnancy (outcome 2) and who consumed FA before the pregnancy (outcome 3). For comparison purposes, a group was formed by puerperal women who did not consume FA during pregnancy with those who did not take Iron and with those who did not consume FA before the pregnancy. The consumption of FA and Iron were assessed by means of the composition of the medications reported by the puerperal women in which many consumed these supplements in association with other substances.

The independent variables were: maternal age; schooling appropriate for maternal age; skin color; marital status; family income; whether the pregnancy was planned; place where prenatal care was performed and the number of prenatal consultations. Age was obtained considering complete years at the time of the interview and categorized as less than 20 years old, between 20 to 34 years old and 35 years old or more. The appropriate schooling for maternal age was defined according to the number of complete years of studying and the maternal age: women aged 19 years or older and with 10 years or more of schooling, age-appropriate for schooling; those under 19 years old, years of schooling were subtracted from the age, values over seven years of schooling indicated appropriate to their age.

The skin color was self-reported and classified as white, black, mixed or other. The marital status was dichotomized, considering those who lived with a partner and those who lived without a partner. Family income, analyzed by the amount of minimum wages $(\mathrm{mw})$ received by the family per month, was classified as less than or equal to one minimum wage, between more than 1 to 3 minimum wages and more than three wages. The minimum wage at the time of the data collection was R $\$ 510.00$.

The variable, planned pregnancy, was categorized as yes and no answer. The place where the prenatal care was performed was classified as: public and private. The number of prenatal consultations performed was categorized as less than six consultations and greater than or equal to six consultations, and the second situation was recommended by the Ministry of Health. ${ }^{9}$

Statistical analyzes were performed using the STATA 14.0 statistical program. First, a descriptive analysis of the variables was performed, by presenting absolute frequencies and percentages. A bivariate analysis was performed among all the factors and the outcomes, as a step prior to the multivariate analysis. For the estimates on prevalence ratio (PR), respective confidence intervals and determination of factors statistically associated with outcomes 1 and 2, Poisson model with robust variance was used, due to the frequency of the outcome being greater than $10 \% .13$ For outcome 3 (prevalence less than 10\%), logistic regression was used. The variables that showed an association with the outcome with a significance level less than 0.20 in the bivariate analysis were maintained in the multivariate analysis. In the final model, variables with $p$ value was less than 0.05 were considered significant. BRISA was approved by the Research Ethics Committee at the Hospital Universitário da UFMA (CEP document n. 223/2009) and respected the ethical principles contained in Resolution No. 196/96 of the Conselho Nacional de Saúde (National Health Council) and its complementaries.

\section{Results}

Of the puerperal women interviewed, 3,028 $(75.02 \%)$ reported being between 20 and 34 years old; 2,664 $(66.01 \%)$, had adequate schooling for maternal age; 2,671 (66.18\%), had mixed skin color; 3,336 (82.66\%), had a partner; and 1,989 (49.28\%), had a family income between 1 to 3 minimum wages. The pregnancy was considered unplanned by $2,681(66.43 \%)$ and the prenatal consultations performed were mostly at the public health service. $3,218(79.73 \%)$ and $2,303(57.06 \%)$ had less than six 
prenatal consultations. (Table 1).

The prevalence of consuming FA and Iron during pregnancy were respectively, $77.27 \%(\mathrm{n}=3.118)$ and $84.98 \%(n=3.429)$. However, only $0.37 \%(n=15)$ of the puerperal women reported consuming them before the pregnancy. The distribution of independent variables, according to the outcomes are shown in Table 1.

In the unadjusted analysis (Table 2), the variables associated with the consumption of FA during pregnancy were: adequate schooling for maternal age $(\mathrm{PR}=1.12 ; p<0.001)$, family income greater than one minimum wage ( 1 to $3 \mathrm{mw}$ : $\mathrm{PR}=1.08$; above $3 \mathrm{mw}$ : $\mathrm{PR}=1.13 ; p<0.001)$ and had performed prenatal consultations at the private health service $(\mathrm{PR}=1.07 ; p=0.001)$. For the consumption of Iron during pregnancy, the associated variables were: maternal age less than 20 years old $(\mathrm{PR}=1.04$; $p=0.029)$, family income greater than one minimum wage ( 1 to $3 \mathrm{mw}$ : $\mathrm{PR}=1.08$; above $3 \mathrm{mw}$ : $\mathrm{PR}=1.13$; $p<0.001)$ and had performed six or more prenatal consultations ( $\mathrm{PR}=0.97 ; p=0.030)$. However, the variables associated with the consumption of FA before pregnancy were only: maternal age greater than 35 years $(\mathrm{PR}=4.48 ; p=0.051)$ and planned pregnancy $(\mathrm{PR}=2.98 ; p=0.039)$.

In the adjusted analysis (Table 3 ), the variables associated with the consumption of FA during pregnancy were: adequate schooling for maternal age $(\mathrm{PR}=1.10 ; p<0.001)$ and family income above three minimum wages $(\mathrm{PR}=1.08 ; p=0.036)$; for puerperal women who took Iron during pregnancy, only the maternal age less than 20 years old $(\mathrm{PR}=1.04$; $p=0.042$ ); and for those who consumed FA before the pregnancy, no variable was found to be statistically significant.

Table 1

\begin{tabular}{|c|c|c|c|c|c|c|c|c|}
\hline \multirow[t]{2}{*}{ Characteristics } & \multicolumn{2}{|c|}{ Total } & \multicolumn{2}{|c|}{$\begin{array}{l}\text { Consumption of } \\
\text { folic acid during } \\
\text { pregnancy }\end{array}$} & \multicolumn{2}{|c|}{$\begin{array}{l}\text { Consumption of } \\
\text { Iron during } \\
\text { pregnancy }\end{array}$} & \multicolumn{2}{|c|}{$\begin{array}{l}\text { Consumption of } \\
\text { of folic acid before } \\
\text { pregnancy }\end{array}$} \\
\hline & $\mathrm{n}$ & $\%$ & $\mathrm{n}$ & $\%$ & $\mathrm{n}$ & $\%$ & $\mathrm{n}$ & $\%$ \\
\hline \multicolumn{9}{|l|}{ Age (years) } \\
\hline$<20$ & 667 & 16.53 & 516 & 77.36 & 587 & 88.01 & 3 & 0.45 \\
\hline $20-34$ & 3028 & 75.02 & 2339 & 77.27 & 2551 & 84.27 & 8 & 0.26 \\
\hline$\geq 35$ & 341 & 8.45 & 263 & 77.13 & 291 & 85.34 & 4 & 1.17 \\
\hline \multicolumn{9}{|l|}{ Schooling } \\
\hline Adequate & 2664 & 66.01 & 2138 & 80.29 & 2253 & 84.60 & 13 & 0.49 \\
\hline Inadequate & 1372 & 33.99 & 980 & 71.43 & 1176 & 85.71 & 2 & 0.15 \\
\hline \multicolumn{9}{|l|}{ Skin color } \\
\hline White & 784 & 19.43 & 607 & 77.42 & 649 & 82.78 & 5 & 0.64 \\
\hline Black & 523 & 12.96 & 393 & 75.24 & 450 & 86.21 & 2 & 0.38 \\
\hline Mixed & 2671 & 66.18 & 2076 & 77.72 & 2284 & 85.51 & 8 & 0.30 \\
\hline Other & 58 & 1.43 & 42 & 72.41 & 46 & 79.31 & 0 & - \\
\hline \multicolumn{9}{|l|}{ Marital status } \\
\hline With partner & 3336 & 82.66 & 2595 & 77.81 & 2837 & 85.07 & 12 & 0.36 \\
\hline No partner & 700 & 17.34 & 523 & 74.71 & 592 & 84.57 & 3 & 0.43 \\
\hline \multicolumn{9}{|l|}{ Family income } \\
\hline$\leq 1 \mathrm{mw}$ & 708 & 17.54 & 504 & 71.29 & 589 & 83.31 & 2 & 0.28 \\
\hline $1-3 \mathrm{mw}$ & 1989 & 49.28 & 1532 & 77.02 & 1709 & 85.92 & 2 & 0.10 \\
\hline$>3 \mathrm{mw}$ & 1339 & 33.18 & 1082 & 80.81 & 1131 & 84.47 & 11 & 0.82 \\
\hline \multicolumn{9}{|l|}{ Planned pregnancy } \\
\hline Yes & 1355 & 33.57 & 1060 & 78.23 & 1146 & 84.58 & 9 & 0.66 \\
\hline No & 2681 & 66.43 & 2058 & 76.79 & 2283 & 85.19 & 6 & 0.22 \\
\hline \multicolumn{9}{|l|}{ Prenatal care } \\
\hline Public health service & 3218 & 79.73 & 2452 & 76,22 & 2751 & 85.51 & 4 & 0.12 \\
\hline Private health service & 818 & 20.27 & 666 & 81.42 & 678 & 82.89 & 11 & 1.34 \\
\hline \multicolumn{9}{|l|}{$\begin{array}{l}\text { Number of prenatal } \\
\text { consultations performed }\end{array}$} \\
\hline$<6$ & 2303 & 57.06 & 1750 & 76.02 & 1981 & 86.06 & 5 & 0.22 \\
\hline$\geq 6$ & 1733 & 42.94 & 1368 & 78.94 & 1448 & 83.55 & 10 & 0.58 \\
\hline
\end{tabular}

$\mathrm{mw}=$ minimum wages. 
Unadjusted analysis of factors associated with the consumption of folic acid and iron supplementation during pregnancy and folic acid before pregnancy in puerperal women. São Luís, MA, Brazil, 2010.

\begin{tabular}{|c|c|c|c|c|c|c|c|c|c|}
\hline \multirow[t]{2}{*}{ Variables } & \multicolumn{3}{|c|}{$\begin{array}{l}\text { Consumption of folic } \\
\text { acid during pregnancy }\end{array}$} & \multicolumn{3}{|c|}{$\begin{array}{l}\text { Iron use during } \\
\text { pregnancy }\end{array}$} & \multicolumn{3}{|c|}{$\begin{array}{c}\text { Use of folic acid before } \\
\text { pregnancy }\end{array}$} \\
\hline & PR & $\mathrm{Cl} 95 \%$ & $p$ & PR & $\mathrm{Cl} 95 \%$ & $p$ & PR & $\mathrm{Cl} 95 \%$ & $p$ \\
\hline Age (years) & & & 0.996 & & & 0.029 & & & 0.051 \\
\hline$<20$ & 1.00 & $0.96-1.05$ & & 1.04 & $1.01-1.08$ & & 1.70 & $0.45-6.44$ & \\
\hline $20-34$ & 1 & - & & 1 & - & & 1 & - & \\
\hline$\geq 35$ & 1.00 & $0.94-1.06$ & & 1.01 & $0.97-1.06$ & & 4.48 & $1.34-14.95$ & \\
\hline Schooling & & & $<0.001$ & & & 0.344 & & & 0.111 \\
\hline Adequate & 1.12 & $1.08-1.17$ & & 0.99 & $0.96-1.01$ & & 3.36 & $0.76-14.91$ & \\
\hline Inadequate & 1 & - & & 1 & - & & 1 & - & \\
\hline Skin color & & & 0.564 & & & 0.179 & & & 0.413 \\
\hline White & 1 & - & & 1 & - & & 1 & - & \\
\hline Black & 0.97 & $0.91-1.03$ & & 1.04 & 0.99-1.09 & & 0.60 & $0.11-3.10$ & \\
\hline Mixed & 1.00 & $0.96-1.05$ & & 1.03 & $1.00-1.07$ & & 0.47 & $0.15-1.43$ & \\
\hline Other & 0.93 & $0.79-1.10$ & & 0.96 & $0.84-1.10$ & & - & - & \\
\hline Marital status & & & 0.089 & & & 0.741 & & & 0.786 \\
\hline With partner & 1 & - & & 1 & - & & 1 & - & \\
\hline No partner & 0.96 & $0.92-1.00$ & & 0.99 & $0.96-1.03$ & & 1.19 & $0.33-4.23$ & \\
\hline Family income & & & $<0.001$ & & & $<0.001$ & & & 0.014 \\
\hline$\leq 1 \mathrm{mw}$ & 1 & - & & 1 & - & & 1 & - & \\
\hline $1-3 \mathrm{mw}$ & 1.08 & $1.02-1.14$ & & 1.08 & $1.02-1.14$ & & 0.35 & $0.05-2.52$ & \\
\hline$>3 \mathrm{mw}$ & 1.13 & 1.07-1.19 & & 1.13 & $1.07-1.19$ & & 2.92 & $0.64-13.21$ & \\
\hline Planned pregnancy & & & 0.298 & & & 0.610 & & & 0.039 \\
\hline Yes & 1.02 & $0.98-1.05$ & & 0.99 & $0.96-1.02$ & & 2.98 & $1.06-8.39$ & \\
\hline No & 1 & - & & 1 & - & & 1 & - & \\
\hline Prenatal care & & & 0.001 & & & 0.074 & & & - \\
\hline Public health service & 1 & - & & 1 & - & & - & - & \\
\hline Private health service & 1.07 & $1.03-1.11$ & & 0.97 & $0.94-1.00$ & & - & - & \\
\hline \multicolumn{10}{|l|}{ Number of prenatal } \\
\hline consultations performed & & & 0.027 & & & 0.030 & & & - \\
\hline$<6$ & 1 & - & & 1 & - & & - & - & \\
\hline$\geq 6$ & 1.04 & $1.00-1.07$ & & 0.97 & $0.94-0.99$ & & - & - & \\
\hline
\end{tabular}

$\mathrm{PR}=$ Prevalence Ratio; $\mathrm{Cl} 95 \%=95 \%$ Confidence Interval; $\mathrm{mw}=$ minimum wages.

\section{Discussion}

The prevalence of consuming FA during pregnancy alters according to the populations' characteristics and the period of consumption. ${ }^{14}$ In this study, the prevalence found in the FA supplementation during pregnancy was close to the one found in the Netherlands 15 and the USA 16 and higher than the one found in researches conducted in China, 17 Spain 18 and in some Brazilian cities. 7,14,19,20

As FA, the prevalence found in the consumption of Iron during pregnancy was higher than those reported in the literature, which were below $66 \% .21,22,23$
In relation to the consumption of FA before pregnancy, the prevalence was only $0.37 \%$, close to the one found in the literature for the periconceptional period, which varies between $0.5 \%$ and $52 \%$ in studies carried out in several countries in the Americas, Europe, Australia and Asia. 24 The developed countries had the highest prevalence, between $17 \%$ to $52 \% .15-18$ In Brazil, only two studies were found that evaluated the specific period of consumption of FA, reporting a prevalence of its consumption in the periconceptional period of $4.3 \%$, in a population-based study composed of 1,509 mothers, ${ }^{8}$ and $8.3 \%$, in another study carried out in the extreme 
Table 3

Adjusted analysis of factors associated with the consumption of folic acid (FA) and iron (I) supplementation during pregnancy and folic acid before pregnancy in puerperal women. São Luís, MA, Brazil, 2010.

\begin{tabular}{|c|c|c|c|c|c|c|c|c|c|}
\hline \multirow[t]{2}{*}{ Variables } & \multicolumn{3}{|c|}{$\begin{array}{l}\text { Consumption of folic } \\
\text { acid during pregnancy }\end{array}$} & \multicolumn{3}{|c|}{$\begin{array}{l}\text { Consumption of Iron } \\
\text { during pregnancy }\end{array}$} & \multicolumn{3}{|c|}{$\begin{array}{l}\text { Consumption of folic } \\
\text { acid before pregnancy }\end{array}$} \\
\hline & PR & $\mathrm{Cl} 95 \%$ & $p$ & PR & $\mathrm{Cl} 95 \%$ & $p$ & PR & $\mathrm{Cl} 195 \%$ & $p$ \\
\hline Age (years) & & & - & & & 0.042 & & & 0.072 \\
\hline$<20$ & - & - & & 1.04 & $1.01-1.08$ & & 3.55 & $0.83-15.20$ & \\
\hline $20-34$ & - & - & & 1 & - & & 1 & - & \\
\hline$\geq 35$ & - & - & & 1.02 & $0.97-1.07$ & & 3.21 & $0.94-10.90$ & \\
\hline Schooling & & & $<0.001$ & & & - & & & 0.304 \\
\hline Adequater & , 10 & $1.06-1.15$ & & - & - & & 2.37 & $0.46-12.30$ & \\
\hline Inadequate & 1 & - & & 1 & - & & 1 & - & \\
\hline Skin color & & & - & & & 0.306 & & & - \\
\hline White & 1 & - & & 1 & - & & - & - & \\
\hline Black & - & - & & 1.04 & 0.99-1.09 & & - & - & \\
\hline Mixed & - & - & & 1.03 & $0.99-1.06$ & & - & - & \\
\hline Other & - & - & & 0.96 & $0.83-1.09$ & & - & - & \\
\hline Marital status & & & 0.242 & & & - & & & - \\
\hline With partner & 1 & - & & 1 & - & & - & - & \\
\hline No partner & 0.97 & $0.93-1.02$ & & - & - & & - & - & \\
\hline Family income & & & 0.036 & & & 0.106 & & & 0.058 \\
\hline$\leq 1 \mathrm{mw}$ & 1 & - & & 1 & - & & 1 & - & \\
\hline $1-3 \mathrm{mw}$ & 1.06 & $1.00-1.12$ & & 1.04 & $1.00-1.08$ & & 0.34 & $0.05-2.44$ & \\
\hline$>3 \mathrm{mw}$ & 1.08 & $1.02-1.14$ & & 1.04 & $1.00-1.09$ & & 2.19 & $0.42-11.37$ & \\
\hline Planned pregnancy & & & - & & & - & & & 0.063 \\
\hline Yes & - & - & & - & - & & 2.77 & $0.95-8.08$ & \\
\hline No & - & - & & - & - & & 1 & & \\
\hline Prenatal care & & & 0.740 & & & 0.395 & & & - \\
\hline Public health service & 1 & - & & 1 & - & & - & - & \\
\hline Private health service & 1.01 & $0.96-1.05$ & & 0.98 & $0.94-1.02$ & & - & - & \\
\hline \multicolumn{10}{|l|}{ Number of prenatal } \\
\hline consultations performed & & & 0.815 & & & 0.116 & & & - \\
\hline$<6$ & 1 & - & & 1 & - & & - & - & \\
\hline$\geq 6$ & 0.99 & $0.96-1.03$ & & 0.98 & $0.95-1.00$ & & - & - & \\
\hline
\end{tabular}

$\mathrm{PR}=$ Prevalence Ratio; $\mathrm{Cl} 95 \%=95 \%$ Confidence Interval; $\mathrm{mw}=$ minimum wages.

south of Brazil with 2,685 puerperal women, where it was evidenced that $78.6 \%$ consumed FA supplementation in the first trimester of pregnancy. 14

The high prevalence of consumption of FA and Iron during pregnancy may be due to the fact that we have considered not only the consumption of these supplements in an isolated form, but also in association with other substances and to a positive response to programs developed in Brazil, such as the Programa Nacional de Suplementação de Ferro (National Iron Supplementation Program), established by the Decree No. 730 in May 13, 2005, which they are available free of charge and has an aim to prevent and control anemia through prophy- lactic administration of iron supplements for children aged 6 to 24 months of age, pregnant women (also including folic acid) and women up to their third month postpartum and / or post abortion. The consumption of these supplements in pregnant women is recommended by the World Health Organization 10 and adopted by the Ministry of Health for prenatal care. 10

However, the low prevalence of FA consumption in the periconceptional period demonstrates the necessity to promote more educational actions. This necessity can also be seen through studies such as the one carried out by Mezzomo et al. 7 who found that only $22.2 \%$ of the women who consumed folic 
acid during pregnancy reported knowing the appropriate period for its consume and only $12.8 \%$ knew about the specific benefit.

As in other studies, after adjusting for confounding variables, the determining factors for FA consumption during pregnancy were adequate for schooling and family income, having a higher consumption of both refers to higher levels of schooling and income. $7,14,19,24$

The increase of income and schooling influencing a higher consumption of FA during pregnancy could be explained, respectively, by the fact that these women have better access to the supplement and information on how important its consume is.

Regarding to the type of prenatal care (public or private health service), we found no association between FA supplementation and the type of service used in prenatal consultations, which we consider to be due to the Programa Nacional de Suplementação de Ferro (National Iron Supplementation Program), which it encourages the consumption and these supplements are available free of charge for pregnant women at the public health service.

A different result was found by Mezzomo et al.,7 in the city of Pelotas, Rio Grande do Sul, in which pregnant women who received prenatal care at the private health service consumed twice as much of FA as those who were treated at the public health service. However, this study by Mezzomo et al. 7 refers to the period between April 1 and August 15, 2006, when the Programa Nacional de Ferro (National Iron Program) was still initiating.

For the consumption of Iron during pregnancy, the determining factor was only the maternal age below 20 years old. This demonstrates that the recommendation given by WHO is that all pregnant adolescents and adult women should be supplemented with iron daily, in which this is not being fulfilled. We believe that this non-adherence in other age groups may be due to the indiscriminate controversies about iron replacement, since studies describe negative aspects of this, such as increased platelet aggregation with risk of thrombosis, development of hypertension and placental infarctions, with consequent delayed intrauterine growth of the fetus and increased oxidative stress. ${ }^{25,26}$

In addition, there is a selective recommendation from health professionals regarding iron supplementation, which should occur individually. It is also considered the fact that there is a greater need for this supplement in pregnant adolescents, since pregnancy in this age group is considered to be of high risk, from a physical-biological point of view, adolescents are more likely to have anemia and many already become anemic at pregnancy, which is an aggravated problem during pregnancy that increases the risk of premature babies with lower weight and greater need for cesarean sections.22,27 Cesar et al.,22 also reported an association with higher consumption of Iron in pregnant adolescents. Ugwu et al.,23 found different associated factors when comparing to our study. For these authors, the higher education level and high social class were factors significantly associated with the consumption of Iron supplementation, after adjusting other confounding factors, the main barriers to comply with this supplementation are: gastrointestinal side effects $(41.7 \%)$, lack of accessibility to iron supplements due to price $(28.3 \%)$ and by forgetfulness $(15.0 \%)$.

In the unadjusted analysis on the consumption of FA before pregnancy, only maternal age above thirty-five years old $(\mathrm{PR}=4.48, p=0.051)$ and planned pregnancy $(\mathrm{PR}=2.98 ; p=0.039)$ were associated and after adjusting for confounding variables, there was no determining factor for this consumption. These results may have been due to a low prevalence of puerperal women who consumed FA before pregnancy, which may have reduced the strength in this study, making it impossible to detect statistically significant associations.

Another study reported the association of consuming FA in the periconceptional period only with planned pregnancy. 24 This portrays the nonconsumption of this supplement by women at childbearing age, which is contrary to what is recommended by WHO, 10 since most pregnancies are unplanned. 24

Among other very few studies that analyzed the factors associated with the consumption of FA in the periconceptional period, Lawal and Adeleye, 28 in Nigeria, found that non-intake was associated with pregnant women belonging to a low social class, with limited schooling and began their prenatal care very late. McGuire et al. ${ }^{29}$ analyzed the factors associated with the consumption of FA in the recommended and non-recommended amount in the periconceptional period, in a cohort composed of 61.252 women. The authors reported that $85 \%$ of these women took FA at some point during the periconceptional period, however, only $28 \%$ took it as recommended. Factors associated with taking the recommended amount were nulliparity, first prenatal consultation before 12 weeks of gestation, older maternal age, private health care and those who 
underwent fertility treatment. Factors associated with taking less than recommended or not taking were unplanned pregnancies, lower socioeconomic status, non-Irish nationality and smokers.

A possible weakness in our study could be the failure in verifying the consumption of the supplements of interest (folic acid and iron), if the puerperal woman did not mention spontaneously, however the high prevalence found in the consumption of these supplements in the sample excludes the need for this confirmation. One limitation was the recall bias, since the questionnaire was applied only after childbirth, thus this may have increased the possibility of the puerperal woman not to remember the consumption of some medications taken during pregnancy. As a strong point, the results were obtained from a representative sample of the population of women who delivered at a hospital or maternity hospital in the city of São Luís, Maranhão, since most of the studies described in the literature were composed of convenience samples.

Based on the above considerations, we conclude that a high percentage of puerperal women consumed supplements of FA and Iron during pregnancy, however the recommended consumption of FA before pregnancy was low and that maternal, social and economic factors may have influenced the consumption of the recommended supplements at pregnancy.

We believe that the population's lack of knowledge about the importance of consuming FA in the periconceptional period and the high rate of unplanned pregnancy may be driven to this low adherence of periconceptional consumption of FA

\section{References}

1. Melo ASO, Assunção PL, Gondim SSR, Carvalho DF, Amorim MMR, Benicio MHD, Cardoso MAA. Estado nutricional materno, ganho de peso gestacional e peso ao nascer. Rev Bras Epidemiol. 2007; 10 (2): 249-57.

2. Marqui PA, Kuroyanagi FI, Foss MS, Dobre NR, Souza DN, Lima E. Principais Fatores da Baixa Adesão ao Uso de Ácido Fólico. UNOPAR Cient Ciênc Biol Saúde. 2014; 16 (2): 141-8

3. Fekete K, Berti C, Cetin I, Hermoso M, Koletzko BV, Decsi T. Perinatal folate supply: relevance in health outcome parameters. Matern Child Nutr. 2010; 6 (Supl. 2): 23-38.

4. Vannucchi H, Monteiro T. Funções plenamente reconhecidas de nutrientes: ácido fólico. São Paulo: International Life Sciences Institute do Brasil (ILSI Brasil); 2010.

5. Peña-Rosas JP, De-Regil LM, Garcia-Casal MN, Dowswell T. Daily oral iron supplementation during pregnancy. Cochrane Database Syst Rev. 2015; Jul 22; 7: CD004736. verified in our study. Therefore, a more effective approach regarding the importance of this supplement for women with low schooling and income, carrying out more campaigns on the importance of this supplement, encouraging the consumption and the free access to women of childbearing age can have effective measures.

In this study, we evaluated only the prevalence and factors associated with the consumption of FA and Iron in pregnant women, without delaying with the daily dosage, prescription, form of consuming, reasons for not taking it and the duration of consuming it by pregnant women. Therefore, more studies evaluating these characteristics and their associated factors are necessary to identify other variables related to the consumption of FA and Iron in pregnant women, in order to plan more effective interventions, since there is little information about this in the literature, especially regarding Brazilian data.

\section{Acknowledgements}

To CNPq, FAPESP, FAPEMA and PRONEX for the financial support in carrying out this research.

\section{Authors' contribution}

Lima RM carried out all the planning, execution, data analysis and preparation of this manuscript. Leite EVNC and Furtado DF performed the reading and review of the manuscript. Santos AM guided the research. All authors approved the final version of this article.

6. Cantor AG, Bougatsos C, Dana T, Blazina I, McDonagh M. Routine iron supplementation and screening for iron deficiency anemia in pregnancy: a systematic review for the U.S. Preventive Services Task Force. Ann Intern Med. 2015; 162 (8): 566-76

7. Mezzono CLS, Garcias GL, Sclowitz ML, Sclowitz IT, Brum CB, Fontana T, Unfried RI. Prevenção de defeitos do tubo neural: prevalência do uso da suplementação de ácido fólico e fatores relacionados em gestantes na cidade de Pelotas, Rio Grande do Sul, Brasil. Cad Saúde Pública. 2007; 23 (11): 2716-26.

8. Blencowe H, Cousens S, Modell B, Lawn J. Folic acid to reduce neonatal mortality from neural tube disorders. Int $\mathrm{J}$ Epidemiol. 2010; 39 (Supl. 1): i110-i21.

9. Brasil. Ministério da Saúde. Atenção ao pré-natal de baixo risco. Caderno de Atenção Básica, n.32. Série A. Normas e Manuais Técnicos. Brasília, DF; 2012. 
10. OMS (Organização Mundial da Saúde). Diretriz: suplementação diária de ferro e ácido fólico em gestantes. Genebra 2013.

11. Sununtnassuk C, D'Agostino A, Fiedler IJL. Iron + folic acid distribution and consumption through antenatal care identifying barriers across countries. Public Health Nutr. 2015; 29: 1-11.

12. Gaiva MAM, Corrêa ER, Santos EARE. Perfil clínico epidemiológico de crianças e adolescentes que vivem e convivem com espinha bífida. Rev Bras Cresc Desenv Hum. 2011; 21 (1): 99-110.

13. Coutinho LMS; Scazufca M; Menezes PR. Métodos para estimar razão de prevalência em estudos de corte transversal. Rev Saúde Pública. 2008; 42 (6): 992-8.

14. Linhares AO, Cesar JA. Suplementação de Ácido Fólico entre gestantes no extremo Sul do Brasil: prevalência e fatores associados. Ciência Saúde Coletiva. 2017; 22 (2): $535-42$

15. Timmermans S, Jaddoe VW, Mackenbach JP, Hofman A, Steegers-Theunissen RP, Steegers EA. Determinants of folic acid use in early pregnancy in a multi-ethnic urban population in The Netherlands: the Generation R study. Prevent Med. 2008; 47 (4): 427-32

16. Branum AM, Bailey R, Singer BJ. Dietary supplement use and folate status during pregnancy in the United States. J Nutr. 2013; 143 (4): 486-92.

17. Xing XY, Tao FB, Hao JH, Huang K, Huang ZH, Zhu XM, $\mathrm{Xu}$ YY, Sun Y. Periconceptional folic acid supple $\neg$ mentation among women attending antenatal clinic in Anhui, China: data from a population-based cohort study. Midwifery. 2012; 28 (3): 291-7

18. Pastor-Valero M, Navarrete-Munoz EM, Rebagliato M, Iniguez C, Murcia M, Marco A, Ballester F, Vioque J. Periconceptional folic acid supplementation and an $\neg$ thropome measures at birth in a cohort of pregnant tric women in Valencia, Spain. Br J Nutr. 2011; 105 (9): 1352-60.

19. Barbosa L, Ribeiro DQ, Faria FC, Nobre LN, Lessa AC. Fatores associados ao uso de suplemento de ácido fólico durante a gestação. Rev Bras Ginecol Obstet. 2011; 33 (9): 246-51.
20. LunetN, Rodrigues T, Coreia S, Barros H. Adequacy of prenatal care as a major deternunant of folic acid, iron, and vitamin intake during pregnancy. Cad Saúde Pública. 2008; 24 (5): 1151-7.

21. Gebremedhin S, Samuel A, Mamo G, Moges T, Assefa T. Coverage, compliance and factors associated with utilization of iron supplementation during pregnancy in eight rural districts of Ethiopia: a cross-sectional study. BMC Public Health. 2014; 14: 607.

22. Cesar JA, Dumith SC, Chrestani MAD, Mendoza-Sassi RA. Suplementação com sulfato ferroso entre gestantes: resultados de estudo transversal de base populacional. Rev Bras Epidemiol. 2013; 16 (3): 729-33.

23. Ugwu EO, Olibe AO, Obi, SN, Ugwu, AO. Determinants of compliance to iron supplementation among pregnant women in Enugu, Southeastern Nigeria. Nigerian J Clin Practice. 2014; 17 (5): 608-12.

24. Ray JG; Singh G; Burrows RF. Evidence for suboptimal use of periconceptional folic acid supplents globally. BJOG. 2004; 111: 399-408

25. Modotti MTCF; Modotti CC; Marcelino MY; Oliva TB; Dias DS; Dias FNB; Rodrigues NP; Modotti WP. Anemia Ferroprina na Gestação: controvérsias na suplementação de ferro. Medicina (Riberão Preto). 2015; 48 (4): 401-7.

26. Ribot B, Aranda N, Giralt M, Romeu M, Balaguer A, Arija $\mathrm{V}$. Effect of different doses of iron supplementation during pregnancy on maternal and infant health. Ann Hematol. 2013; 92: 221-9.

27. Capanzana MV, Aguila DV, Javier CA, Mendoza TS, Santos-Abalos VM. Adolescent Pregnancy and the First 1000 Days (the Philippine Situation). Asia Pac J Clin Nutr. 2015; 24 (4): 759-66.

28. Lawal TA, Adeleye AO. Determinants of folic acid intake during preconception and in early pregnancy by mothers in Ibadan, Nigeria. Pan Afr Med J. 2014; 19 (113): 1-6.

29. Mcguire M, Cleary B, Sahm L, Murphy DJ. Prevalence and predictors of periconceptional folic acid uptake - prospective cohort study in an Irish urban. Hum Reprod. 2010; 25 (2): $535-43$.
Received on February 15, 2019

Final version presented on November 8, 2019

Approved on January 3, 2020 